\title{
Effects of subsoiling tillage on structure, permeability, and crop yields on compacted Solonetzic and Chernozemic dryland soils in Western Canada
}

\author{
Raul Avila ${ }^{1}$, Jeff Schoenau ${ }^{1}$, Tom King ${ }^{1}$, Bing $\mathrm{Si}^{1}$ and Mike Grevers ${ }^{1}$ \\ ${ }^{I}$ Department of Soil Science, University of Saskatchewan, Saskatoon, SK S7N 5 A8 Canada \\ Corresponding Author: jeff.schoenau@usask.ca
}

\begin{abstract}
Compaction induced by field wheel traffic and dense layers in the subsoil may adversely alter soil structure, impede soil aeration, restrict water infiltration and nutrient uptake, and inhibit plant root development, negatively affecting plant yields. Reclaiming compacted Chernozemic and Solonetzic soils with hardpan B horizons may be possible through subsoiling operations to loosen the soil to depth, e.g. $\sim 0.30$ $\mathrm{m}$. The objective of this study was to evaluate the effect of subsoiling on soil physical properties and plant yield in wheel traffic compacted and non-compacted Chernozemic and Solonetzic soils in southern Saskatchewan Canada. Subsoiling increased air permeability in the compacted Chernozemic soil from $4.5 \times 10^{-7} \mathrm{~m} \mathrm{sec}^{-1}$ to $2.9 \times 10^{-6} \mathrm{~m} \mathrm{sec}^{-1}$. In the compacted Solonetzic soil, subsoiling significantly decreased soil cone index to $1579 \mathrm{kPa}$ compared to 2376 $\mathrm{kPa}$ in the non-subsoiled treatment. Crop yields (hard red spring wheat, dry peas) in the two years following the treatment were similar among tillage and compaction treatments in the Chernozemic soil. However, subsoiling of the compacted Solonetzic soil resulted in a seed yield increase of canola of $\sim 1000 \mathrm{~kg} \mathrm{ha}^{-1}$ in the first year of study and no treatment effect in the second year when wheat was grown. Overall, subsoiling of the compacted soils tended to improve soil physical properties, especially in the Solonetzic soils.
\end{abstract}

\section{KEYWORDS}

Subsoiling, tillage, compaction, permeability, solonetzic, chernozemic.

\section{RÉSUMÉ}

Le compactage causé par la circulation des machines agricoles dans les champs et par les couches denses dans le sous-sol peut altérer négativement la structure du sol, empêcher l'aération du sol, restreindre l'infiltration de l'eau et l'absorption des nutriments, et empêcher le développement des racines des plantes, ce qui affecte négativement les rendements des cultures. La régénération des sols compactés Chernozemic et Solonetzic avec des horizons B compactés peut être possible par des opérations de sous-solage pour ameublir le sol jusqu'à une profondeur d'environ $0,30 \mathrm{~m}$. L'objectif de cette étude était d'évaluer l'effet du soussolage sur les propriétés physiques du sol et le rendement des cultures dans des sols Chernozemic et Solonetzic compactés et non compactés soumis à la circulation véhiculaire dans le sud de la Saskatchewan, Canada. Le sous-solage a augmenté la perméabilité à l'air de $4.5 \times 10^{-7} \mathrm{~m} \mathrm{sec}^{-1}$ à $2.9 \times 10^{-6} \mathrm{~m} \mathrm{sec}^{-1}$ dans le sol compacté Chernozemic. Dans le sol compacté Solonetzic, le sous-solage a diminué de façon significative l'indice de cône du sol à $1579 \mathrm{kPa}$ comparativement à $2376 \mathrm{kPa}$ pour le traitement sans sous-solage. Le rendement des cultures (blé dur rouge de printemps, pois secs) au cours des deux années suivant le traitement était similaire entre les traitements de travail du sol et de compactage dans le sol Chernozemic. Cependant, le sous-solage du sol compacté Solonetzic a entrainé une augmentation du rendement de canola de $\sim 1000 \mathrm{~kg} \mathrm{ha}^{-1}$ au cours de la première année de l'étude et aucun effet du traitement n'a été observé au cours de la deuxième année où du blé a été cultivé. Dans l'ensemble, le sous-solage des sols compactés a eu tendance à améliorer les propriétés physiques du sol, en particulier dans les sols Solonetzic.

\section{MOTS CLÉS}

Sous-solage, travail du sol, compactage, perméabilité, Solonetzic, Chernozemic.

\section{CITATION}

Avila, R., J. Schoenau, T. King, B. Si and M. Grevers. 2020. Effects of subsoiling tillage on structure, permeability, and crop yields on compacted Solonetzic and Chernozemic dryland soils in Western Canada. Canadian Biosystems Engineering/Le génie des biosystèmes au Canada 62: 1.1-1.9. https://doi.org/10.7451/CBE.2020.62.1.1 


\section{INTRODUCTION}

The physical, chemical, and biological attributes of the soil in the root zone of crops can profoundly influence crop yield. In particular, compaction in soils can impose significant changes in the surface and subsurface physical characteristics of the root zone (Soane et al., 1994). For example, when there is compaction in soil, the mean pore size is reduced, leading to reduced air permeability, water infiltration rate, and reduced ability of roots to penetrate and explore the soil volume. The air permeability of the soil is an assessment of the convective transmission of air through the soil under an applied total pressure gradient (Grant and Groenevelt, 2008). It offers information about the size and the continuity of air-filled pores (Hillel, 1980). Soil compaction affects seed germination, seedling emergence and root growth in part by increasing soil cone index. The root growth of most crops is significantly reduced when the soil cone index is above $2500 \mathrm{kPa}$ (Krzic et al., 1999; Kuang et al., 2012; Osman, 2013). Compaction may be addressed by subsurface tillage, termed subsoiling, in which an implement with a foot or share at the bottom of a shank is used to lift and loosen the soil at the depth of operation. Compared to deep ripping, subsoiling does not invert the soil. Furthermore, reduced surface soil disturbance can be accomplished in subsoiling using an implement with shanks of low cross-sectional area. Although a previous study has examined the effect of subsoiling on soil properties in Western Canadian soils (Grevers and deJong, 1993), no studies have evaluated subsoiling effects on compacted soils using modern minimum surface disturbance subsoilers.

Tillage of soils, including subsoiling and deep ripping, can significantly affect soil physical and hydraulic properties, but impacts on grain and biomass yield can be variable (Grevers \& de Jong, 1992; Cai et al., 2014; Elzubeir, 2014). The size and the stability of soil aggregates are often impacted by tillage disturbances, which then influence hydraulic conductivity, water retention, soil crusts, and erodibility (Dexter, 1988). Excessive compaction in wet Chernozemic and Solonetzic soils induced by field traffic may adversely alter soil structure, inhibit soil aeration, restrict water infiltration and nutrient uptake, and inhibit plant root development, affecting plant yields. Subsoiling at depth may be a solution to improve soil physical conditions in compacted Chernozemic and Solonetzic subsoils. While previous research in Western Canada has evaluated the effect of subsoiling on Solonetzic soils with naturally hard B horizons (Grevers and de Jong, 1993), no studies have evaluated the influence of subsoiling on Chernozemic soils or Solonetzic soils that have been exposed to compaction from localized wheel traffic. There is an opportunity to apply subsoiling to just those areas of the field, such as wheel tracks that have been identified as having potential physical limitations, which may be termed "precision subsoiling." The objective of the work described in this paper was to determine how soil conditions and crop yield are affected by specific subsoiling of wheel traffic compacted zones of Chernozemic and Solonetzic soils using a low surface disturbance subsoiler. Soil properties evaluated included soil density, strength, air and water permeability, along with grain and straw yield of canola, wheat and pea grown in rotation on the soils.

\section{MATERIALS AND METHODS}

The study was conducted in south-central Saskatchewan at the border of the Brown and Dark Brown soil-climatic zones near the town of Central Butte. In this general location, two sites representing typical farm fields in southern Saskatchewan were set up where subsoiling treatments were evaluated on compacted and noncompacted soils in each. One site was located on Chernozemic (Orthic Brown Chernozem) soils of the Haverhill association that dominate the south of Central Butte (SCB). In contrast, the other site was located on Solonetz (Solodized Solonetz) soils with a dense hard B horizon restricting growth that dominate north of Central Butte (NCB) of the Echo soil association.

\section{Treatments and experimental design}

South Central Butte (SCB) The precision subsoiling field study at the SCB site was set up as a randomized complete block design within a 30-ha field with four replicates of each treatment. Within each block, the treatments were randomized. Short-term wheel traffic compaction areas were set up prior to the imposition of the tillage treatments. The treatments consisted of no-tillage on compacted and non-compacted zones and subsoiling tillage imposed on compacted and non-compacted zones. The randomized blocks were first subdivided into two 0.30 ha subplots: a control treatment with no subsoiling tillage on wheel traffic compacted and non-compacted zones and the subsoiled treatment with subsoil tillage on wheel traffic compacted and non-compacted zones. There were four replicates of each treatment. Alleyways separating the blocks were established to allow for equipment movement and access to all the treatment plots. Each treatment plot was $50.0 \mathrm{~m}$ running east-west by $60.0 \mathrm{~m}$ running north-south. After the plots were marked out, a Ford F600 single axle $2700 \mathrm{~kg}$ grain truck equipped with 10x20 tires and dual rear wheels and loaded with hard red spring wheat to a loaded gross vehicle weight of $10.0 \mathrm{t}$ made three passes in the same wheel tracks before the subsoiling tillage operation to create zones of compacted soil and non-compacted soil within each main plot. Overall, 288 transect points were identified for sampling and mapped out for the study at this location. A John Deere 2100 Minimum-Till Ripper subsoiler equipped with five standards (shanks) utilizing plow type shares spaced $76.0 \mathrm{~cm}$ apart and set to penetrate $0.30 \mathrm{~m}$ into the soil, hitched to a John Deere $6170 \mathrm{M}$ front wheel assist tractor operated at $7.0 \mathrm{~km} \mathrm{hr}^{-1}$, was used to impose the subsoiling treatments in the fall of 2015 (Fig. 1). The SCB site was seeded in the spring of 2016 with hard red spring wheat (T. aestivum var Brandon). In 2017, the plots were seeded to dry green pea ( $P$. sativum var Sage). 

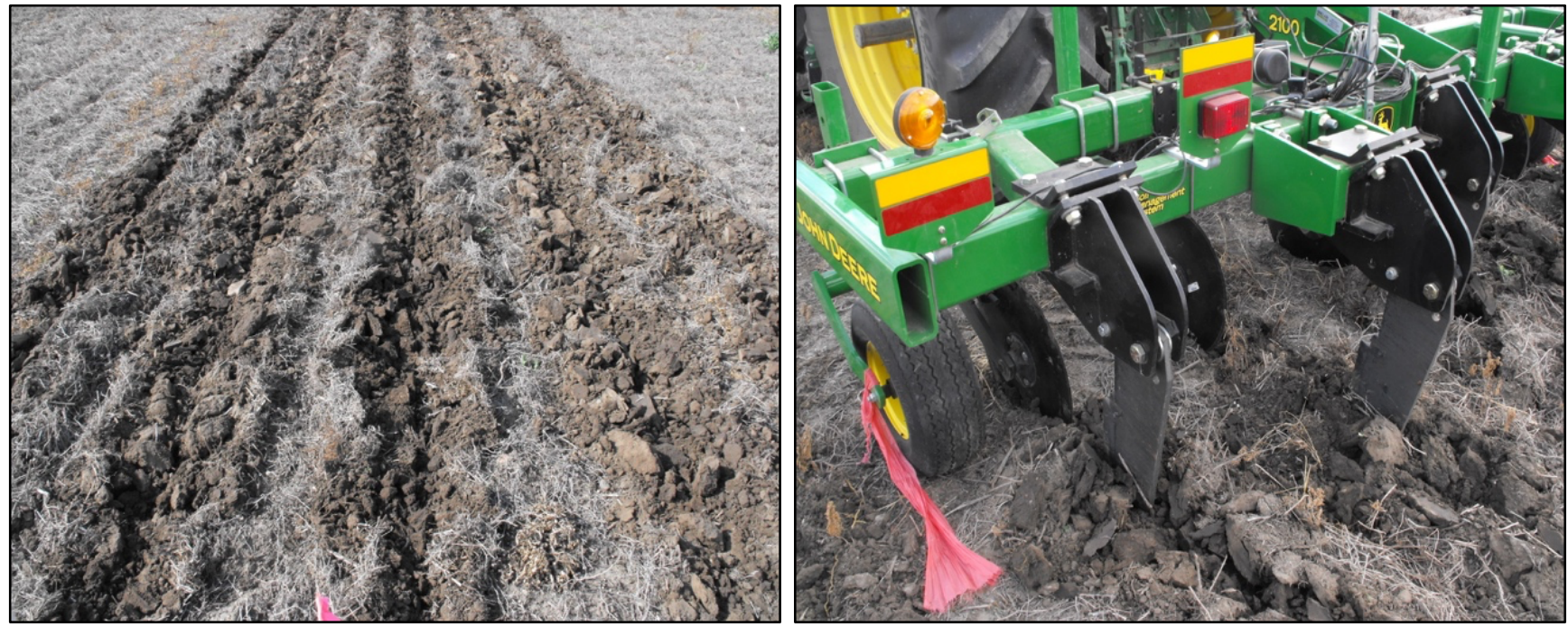

Fig. 1. Loosened soil (left) after one pass with the John Deere 2100 minimum-till subsoiler (right) at the South Central Butte (SCB) site in October 2015.

North Central Butte (NCB) The NCB field study site was set up as two treatments, replicated four times. The treatments consisted of a control treatment where no subsoiling tillage was performed and a subsoiled treatment that received subsoiling tillage. A field area was selected where a long-term (5 years) grain haul road extended across the plot area. Three transects were established with measurement points located in each of the replicated treatments. The following compaction scenarios were evaluated: 1) Pre-Subsoiling Compaction transect: where heavy vehicle and farm machinery wheel traffic occurred over the past 5 years; 2) Post-Subsoiling Compaction transect: in spring 2016, a double axle single wheel livestock trailer and truck loaded with approximately three tonnes of bales travelled over the subsoiling treatment area three times; 3) No-wheel traffic transect: where no soil compaction was performed. As previously shown, the John Deere subsoiling tillage unit and equipment operation were the same as for the SCB site. Subsoiling tillage at the NCB site was conducted in Fall 2015. The NCB site was seeded in spring 2016 with canola (B. napus var LL252). The second cropping season after subsoiling at the NCB site began when seeded to hard red spring wheat (T. aestivum var Brandon) at a rate of $80 \mathrm{~kg} \mathrm{ha}^{-1}$ in the spring of 2017.

\section{Measurements}

Soil bulk density and moisture A soil bulk density and moisture content profile was created from soil samples obtained at each sampling point at depths of $0-0.15,0.15$ 0.30 , and $0.30-0.60 \mathrm{~m}$ using a Gidding truck mounted hydraulic punch with a $5.08 \mathrm{~cm}$ coring unit in the spring of 2016 and 2017.

Soil cone index (Soil strength) Measurements of soil cone index to assess soil strength effects were made using an electronic RIMIK ${ }^{\mathrm{TM}}$ CP40II Cone Penetrometer at the SCB and the NCB sites at each sampling point in spring 2016 and 2017. Penetrometer measurements were repeated at each transect point. Soil strength was measured at the 24 transect measurement points at the NCB site and 288 transect points at the SCB site. The insertion was through the soil vertically at a speed of 2 metres per minute or less, attempting to maintain constant speed during the process. Penetration resistance or cone index (the insertion force divided by the cross-sectional area base of the cone), as determined by a cone penetrometer, is usually used to measure soil cone index (Borghei et al., 2008). In measurement, the soil interacts with the tip and shaft of the penetrometer (Mulqueen et al., 1977). Soil cone index is highly influenced by soil moisture content, particularly if the soil contains clay minerals (Busschera et al., 1997; Kristýna et al., 2013).

Air and water permeability Air and water permeability tests were conducted at 24 transect points at the NCB site and at 18 transect points at the SCB site in each replicate treatment after seeding operations were completed. The instrument to measure air permeability in the field is an air permeameter, with the technique described by Huang et al. (2016). The method consists of inserting a $15 \mathrm{~cm}$ diameter steel tube to a depth of $10 \mathrm{~cm}$ into the soil (Ball and Schjønning, 2002). The tube was sealed, and different airflow rates were applied using the flow controller (FMA6500 by OMEGA Engineering Inc.). Four different airflow rates were applied $\left(0.5,0.7,0.9\right.$, and $\left.1.2 \mathrm{~L} \mathrm{~min}^{-1}\right)$, and the pressures were recorded at each flow rate. The linearity between the airflow and the pressure was checked before recording.

The simplified falling-head (SFH) technique designed by Bagarello et al. (2004) was used to determine hydraulic conductivity $\left(\mathrm{K}_{\mathrm{fs}}\right)$. The method involved applying $10 \mathrm{~L}$ of water onto the soil surface using a single ring (stainless steel square) inserted into the soil to a depth of $12 \mathrm{~cm}$. Measurement was made of the time from the application of the water to the disappearance of the water. The water was added using a perforated plastic bag to add the water quickly but with limited disturbance of the soil surface. A 
Table.1 Soil bulk density at SCB site in spring of 2016 and 2017.

\begin{tabular}{|c|c|c|c|c|c|c|c|}
\hline & \multirow{4}{*}{ Treatment } & \multicolumn{6}{|c|}{ Bulk Density } \\
\hline & & \multicolumn{2}{|c|}{$0-0.15 \mathrm{~m}$} & \multicolumn{2}{|c|}{$0.15-0.30 \mathrm{~m}$} & \multicolumn{2}{|c|}{$0.30-0.60 \mathrm{~m}$} \\
\hline & & 2016 & 2017 & 2016 & 2017 & 2016 & 2017 \\
\hline & & \multicolumn{6}{|c|}{ 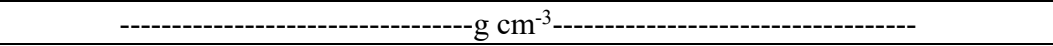 } \\
\hline \multirow{2}{*}{ Subsoiled } & Compacted & $1.39 \mathrm{~b}$ & $1.41 \mathrm{a}$ & $1.57 \mathrm{~b}$ & $1.65 \mathrm{a}$ & $1.62 \mathrm{a}$ & $1.71 \mathrm{a}$ \\
\hline & Non-Compacted & $1.43 b$ & $1.49 \mathrm{a}$ & $1.56 \mathrm{~b}$ & $1.60 \mathrm{ab}$ & $1.60 \mathrm{ab}$ & $1.71 \mathrm{a}$ \\
\hline \multirow{2}{*}{ Non-Subsoiled } & Compacted & $1.56 \mathrm{a}$ & $1.41 \mathrm{a}$ & $1.62 \mathrm{a}$ & $1.62 \mathrm{ab}$ & $1.61 \mathrm{ab}$ & $1.64 \mathrm{a}$ \\
\hline & Non-Compacted & $1.51 \mathrm{a}$ & $1.42 \mathrm{a}$ & $1.54 \mathrm{~b}$ & $1.56 \mathrm{~b}$ & $1.56 \mathrm{~b}$ & $1.63 \mathrm{a}$ \\
\hline
\end{tabular}

${ }^{\dagger}$ Means followed by the same letter in a column are not significantly different $(\mathrm{P}>0.05)$.

single large square ring of dimensions $580 \mathrm{~mm}$ by $420 \mathrm{~mm}$ was used to cover a substantial surface area, including the furrow of the subsoiler and the area in between. PVC plastic cylinder cores were used to take a soil sample to a depth of $5 \mathrm{~cm}$ outside the square ring and inside the ring after the infiltration. The equation to determine the $\mathrm{K}_{\mathrm{fs}}$ is based on the formula of the simplified falling head technique as listed below:

$$
K_{f s}=\frac{(\Delta \theta)}{(1-\Delta \theta) t_{a}}\left[\frac{D}{(\Delta \theta)}-\frac{\left(D+\frac{1}{\alpha^{*}}\right)}{(1-\Delta \theta)} \ln \left(1+\frac{(1-\Delta \theta) \mathrm{D}}{(\Delta \theta)\left(D+\frac{1}{\alpha^{*}}\right)}\right)\right]
$$

To determine the $K_{f s}$, it is necessary to know variables such as (I) $\Delta \theta$ the difference between water content after the infiltration $\left(\vartheta_{2}\right)$ and the initial volumetric water content $\left(\vartheta_{1}\right)$, (II) the depth (D) to which the water was ponded at $\mathrm{t}=0$, (III) the time $\left(\mathrm{t}_{\mathrm{a}}\right)$ that it takes for the depth of water (D) in the ring to infiltrate into the soil completely, (IV) the hydraulic parameter $(\alpha)$ (Bagarello et al., 2004; Ewen, 2015).

Crop grain and straw yields Square meter above-ground crop samples were removed from the plots in the last week of August at maturity in 2016 and 2017. The crop samples were dried at $35^{\circ} \mathrm{C}$ and weighed to determine total biomass yield. The samples were then threshed, cleaned, and weighed to determine grain yield.

\section{RESULTS and DISCUSSION}

\section{Statistical Analysis}

The Statistical Analysis Software package (SAS) was used to analyze the effect of treatments conducted during the 2016 and 2017 years. At the NCB location, the study was set up as two treatments, so all the collected data at this site were analyzed following the SAS T-TEST. The SCB location study was arranged as a randomized complete block design, so the data analyses were performed using SAS-PROC GLIMMIX.

\section{South Central Butte Site (SCB): Chernozemic Soil}

Soil bulk density The wheel traffic compaction induced in the fall of 2015 significantly increased the soil bulk density in the $15-30 \mathrm{~cm}$ depth measured in the spring of 2016 (Table 1). The lack of effect on the surface density could be explained by the surface soil lifting action of the hoe drill seeding openers. Twum and Nii-Annang (2015) reported in a study of the effect of repeated heavy equipment traffic at a site in Germany that areas that received compaction had increased soil density at depth. The subsoiling treatment imposed in the fall of 2015 had a significant effect $(\mathrm{P} \leq$

Table 2. Air permeability and hydraulic conductivity measured in June of 2016 and 2017 at the SCB site.

\begin{tabular}{|c|c|c|c|c|c|}
\hline & \multirow{5}{*}{ Treatment } & \multicolumn{4}{|c|}{ Measurements } \\
\hline & & \multicolumn{4}{|c|}{$0-0.10 \mathrm{~m}$} \\
\hline & & \multicolumn{2}{|c|}{ Air Permeability } & \multicolumn{2}{|c|}{ Hydraulic Conductivity } \\
\hline & & 2016 & 2017 & 2016 & 2017 \\
\hline & & \multicolumn{4}{|c|}{--or } \\
\hline \multirow[t]{2}{*}{ Subsoiled } & Compacted & $1.72 \times 10^{-4}$ & $6.72 \times 10^{-6}$ & $4.95 \times 10^{-4}$ & $1.20 \times 10^{-3}$ \\
\hline & Non-Compacted & $2.49 \times 10^{-4}$ & $6.12 \times 10^{-6}$ & $7.86 \times 10^{-4}$ & $1.42 \times 10^{-3}$ \\
\hline \multirow[t]{2}{*}{ Non-Subsoiled } & Compacted & $2.70 \times 10^{-5}$ & $1.23 \times 10^{-5}$ & $1.58 \times 10^{-4}$ & $1.78 \times 10^{-3}$ \\
\hline & Non-Compacted & $8.28 \times 10^{-5}$ & $1.10 \times 10^{-5}$ & $4.77 \times 10^{-4}$ & $1.30 \times 10^{-3}$ \\
\hline \multirow[t]{2}{*}{$P$ value } & Subsoiled vs Non-Subsoiled & 0.0315 & 0.0745 & 0.2055 & 0.5142 \\
\hline & Compacted vs Non-Compacted & $0.0007 *$ & 0.2688 & 0.2803 & 0.6157 \\
\hline
\end{tabular}

*Significantly different at $\mathrm{P} \leq 0.05$. 
0.05 ) on lowering soil bulk density in the $0-0.15 \mathrm{~m}$ depth in both compacted and non-compacted soil areas in the spring of 2016. The subsoiling was effective in reducing surface density in the first year of the study. In the $15-30 \mathrm{~cm}$ depth, subsoiling also significantly reduced density measured in the spring of 2016, but there was no effect at the $30-60 \mathrm{~cm}$ depth.

In 2017, soil bulk densities were similar among all treatments, indicating that the effect of compaction and subsoiling diminished over the one-year period. The greatest impact of the subsoiling treatment is evident in the upper depths, where the lifting and shattering action of the subsoiler implement shank and plow type shares reduces soil bulk density. In 2017, soil bulk density values increased slightly in all the treatments at the three different depths $(0$ $0.15,0.15-0.30$, and $0.30-0.60 \mathrm{~m}$ ) that were measured, and there were no significant effects of subsoiling on density in this Chernozemic soil (Table 1).

Air and water permeability Air permeability and hydraulic conductivity assessments were performed in the spring of 2016 and 2017 after seeding using the air permeameter for air permeability and the single ring method for hydraulic conductivity. The measurements were taken in the soil surface $(0-10 \mathrm{~cm})$. Air permeability was lowest in the non-subsoiled compacted soil in the first year of the study (2016), but this disappeared in the second year (2017) after subsoiling (Table 2). Subsoiling increased air permeability, especially in the compacted soil, in 2016. In 2017, however, there were no significant $(P>0.05)$ treatment influences on air permeability. For hydraulic conductivity, there were no significant effects $(P>0.05)$ among treatments. The finding of no significant effect of subsoiling on hydraulic conductivity in this study differs from other studies that have shown that deep tillage resulted in significantly increased infiltration (Pikul and Aase, 2003; Williams et al., 2006). Nevertheless, in 2016, there was a trend toward higher infiltration in subsoiled treatments. The effect of compaction on reducing infiltration and subsoiling on increasing infiltration is consistent with impacts on soil porosity as revealed in bulk density measurements. Given that the lifting and loosening of the soil occur primarily at the foot of the shank with the implement used in this study, it is not surprising that the effect on surface infiltration is not significant.

Crop yield Wheat grain yield at the SCB site showed a minimal effect of the compaction/subsoiling treatments (Fig. 2), with similar grain yields and no significant difference $(\mathrm{P}>0.05)$ among the treatments. This agrees with previous studies in Saskatchewan that subsoiling did not have significant effects on crop yield (McConkey et al., 1997), and other locations such as in a study by Murdock et al. (1999) that found that crop yield was very similar between tilled and no-tilled treatments near Zanesville, Ohio. The lack of significant effects of the compaction and subsoiling treatments on yield at the SCB site is consistent with soil cone index values of only around $\sim 1200 \mathrm{kPa}$, even in the wheel traffic compacted area.

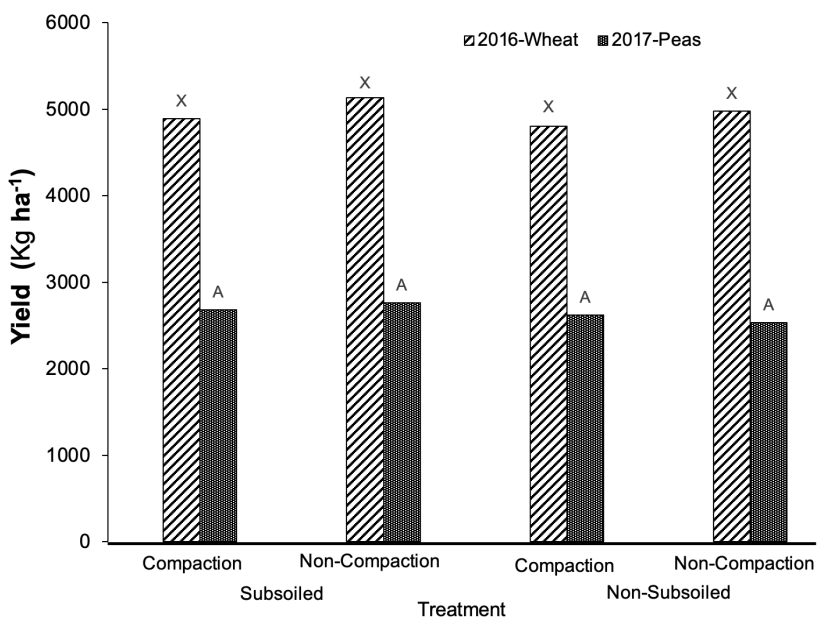

Fig. 2. Wheat (2016) and pea (2017) grain yields (kg ha-1) at the SCB site. For a crop and year, values that are followed by the same letter $(2016 \mathrm{X}, 2017 \mathrm{~A})$ are not significantly different (P> 0.05).

In 2017, the pea yield was also not significantly affected (P $>0.05$ ) by compaction or subsoiling, and the mean yields were similar among the different treatments (Fig. 2). Increases in crop yield associated with subsoiling have been reported by Varsa et al. (1997), with crop yield increased as long as 5 years after the subsoiling treatment in cornfields. The subsoiling and wheel traffic compaction treatments did not have any evident effect on pea grain yields at the SCB site in 2017, nor were any noteworthy trends. This is consistent with the lack of treatment effect on soil properties like density in the second year following subsoiling treatment. The lack of treatment effects on pea yield in 2017 is also not particularly surprising given that there were no yield differences in wheat grown on the plots in 2016.

\section{North Central Butte site (NCB): Solonetzic Soil}

Soil cone index (strength) The cone penetrometer was used to measure soil strength in the spring of 2016 and 2017 after treatments were imposed in the fall of 2015. At the time of measurement after seeding in the spring, the soil moisture content of the profile was near field capacity. In the spring of 2016, the long-term (5-year) compaction by wheel traffic (pre-compacted non-subsoiled) resulted in the highest cone index at the surface. Sub-soiling in the fall of 2015 significantly reduced the cone index measured the following spring to a depth of about $25 \mathrm{~cm}$, with the effects decreasing with depth (Fig. 3). As expected, the uncompacted control treatment had the lowest strength and subsoiling slightly reduced the cone index in plots where there was no compaction. Overall, subsoiling treatments effectively decreased the soil strength of compacted soil and eliminated issues of high soil strength in wheel trafficaffected areas of the field. While having a limited effect on soil bulk density, the lifting action created by the subsoiler significantly reduced the soil compaction-induced resistance to penetration created by the wheel traffic and natural conditions of this Solonetzic soil. The critical level 


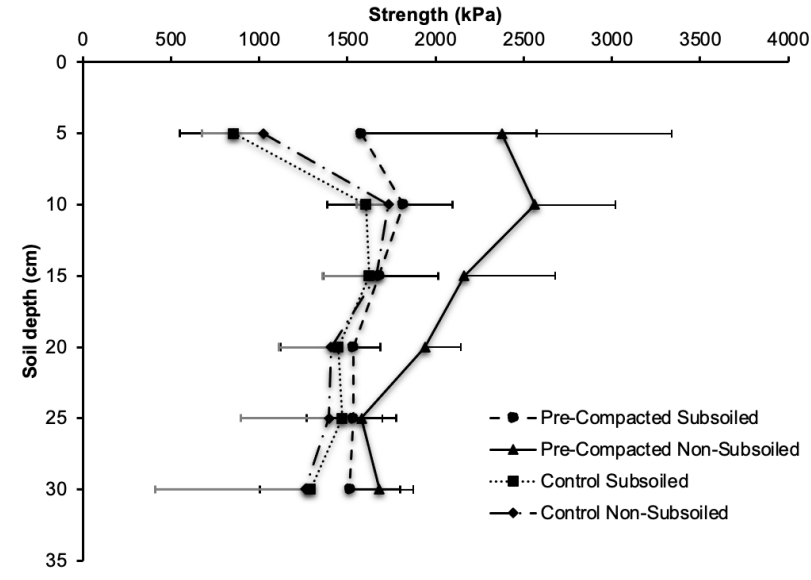

Fig. 3. Soil cone index (penetration resistance $\mathrm{kPa}$ ) at North Central Butte (Solonetzic) site measured using a Rimik $^{\mathrm{TM}}$ cone penetrometer in spring of 2016 subsoiling. Error bars are standard deviation of the mean. Pre-compacted is long-term ( 5 year) wheel traffic compaction prior to subsoiling and control is uncompacted soil.

of penetration resistance for root growth is reported to be $2500 \mathrm{kPa}$ (Busscher et al., 1986). Therefore, it is anticipated that root growth would be impeded in the areas affected by long-term compaction, while the subsoiling, which significantly reduced the cone index, would be expected to contribute to increased root growth. Borghei et al. (2008) reported in their study conducted in the northwest of Iran that there was a significant effect of subsoiling, with cone penetration decrease of up to $43 \%$ in areas that the subsoiling tillage (0.10-0.50 $\mathrm{m}$ of depth) was performed.

Air and water permeability Small and variable effects of treatments on air permeability were observed at the NCB site (Table 3). There is some indication that subsoiling increases air permeability in compacted areas because subsoiling increased mean airflow in both the first and second years of the study. However, the effects were not significant $(\mathrm{P}>0.05)$. This is consistent with a limited effect of the subsoiling on bulk density (porosity) at the NCB site (data not shown).

The effects of tillage on hydraulic conductivity are an important consideration as higher measured hydraulic conductivity indicates a greater rate of water entry into and movement within the soil. In 2016, water infiltration was not significantly $(\mathrm{P}>0.05)$ affected by subsoiling in precompacted and post-compacted areas (Table 3). As for air permeability, the observed lack of large and significant effect of subsoiling on hydraulic conductivity agrees with the limited effect on density in this soil. These findings are different from those reported by Mukhtar et al. (1985) in Iowa, who reported that the effect of tillage treatments on soil water infiltration varied, but deep tillage produced the highest infiltration rates. In the treatment where the soil was compacted following subsoiling, water infiltration appeared to be reduced due to the compaction that occurred after the tillage treatment. In the current study, subsoiling in control plots with no compaction tended to have higher hydraulic conductivity after the first year of treatment. In 2017, there

Table 3. Air permeability and hydraulic conductivity measured in June 2016 and 2017 at the NCB site.

\begin{tabular}{|c|c|c|c|c|c|}
\hline \multicolumn{2}{|c|}{$\begin{array}{ll}\text { Treatment } \\
\end{array}$} & \multicolumn{4}{|c|}{ Measurements } \\
\hline & & \multicolumn{4}{|c|}{$0-0.10 \mathrm{~m}$} \\
\hline & & \multicolumn{2}{|c|}{ Air Permeability } & \multicolumn{2}{|c|}{ Hydraulic Conductivity } \\
\hline & & 2016 & 2017 & 2016 & 2017 \\
\hline & & \multicolumn{4}{|c|}{ 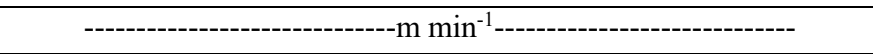 } \\
\hline \multirow[t]{2}{*}{ †re-Compacted } & Subsoiled & $6.90 \times 10^{-5}$ & $7.86 \times 10^{-6}$ & $6.32 \times 10^{-4}$ & $2.13 \times 10^{-3}$ \\
\hline & Non-Subsoiled & $5.87 \times 10^{-5}$ & $6.42 \times 10^{-7}$ & $1.65 \times 10^{-4}$ & $1.67 \times 10^{-3}$ \\
\hline \multirow[t]{2}{*}{ \$Post-Compacted } & Subsoiled & $3.12 \times 10^{-5}$ & $7.44 \times 10^{-6}$ & $8.32 \times 10^{-5}$ & $7.94 \times 10^{-4}$ \\
\hline & Non-Subsoiled & $2.49 \times 10^{-5}$ & $7.20 \times 10^{-6}$ & $5.05 \times 10^{-4}$ & $5.73 \times 10^{-4}$ \\
\hline \multirow[t]{2}{*}{${ }^{\S}$ Control } & Subsoiled & $2.99 \times 10^{-5}$ & $1.37 \times 10^{-5}$ & $2.86 \times 10^{-4}$ & $1.28 \times 10^{-3}$ \\
\hline & Non-Subsoiled & $3.84 \times 10^{-5}$ & $3.64 \times 10^{-6}$ & $6.23 \times 10^{-5}$ & $1.17 \times 10^{-3}$ \\
\hline \multirow[t]{2}{*}{$P$ value } & Subsoiled vs Non-Subsoiled & 0.9125 & 0.0559 & 0.0748 & 0.0632 \\
\hline & Pre-compacted vs Control & 0.9125 & 0.3292 & 0.4416 & 0.2654 \\
\hline
\end{tabular}

†Pre-Compaction is long-term vehicle traffic-induced soil compaction occurring prior to subsoiling treatment being imposed at the North Central Butte (NCB) site in Oct. 2015.

†Post-Compaction is vehicle traffic-induced soil compaction treatment occurring in April 2016 after subsoiling treatment being imposed at the North Central Butte (NCB) site in October 2015.

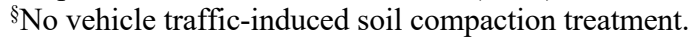




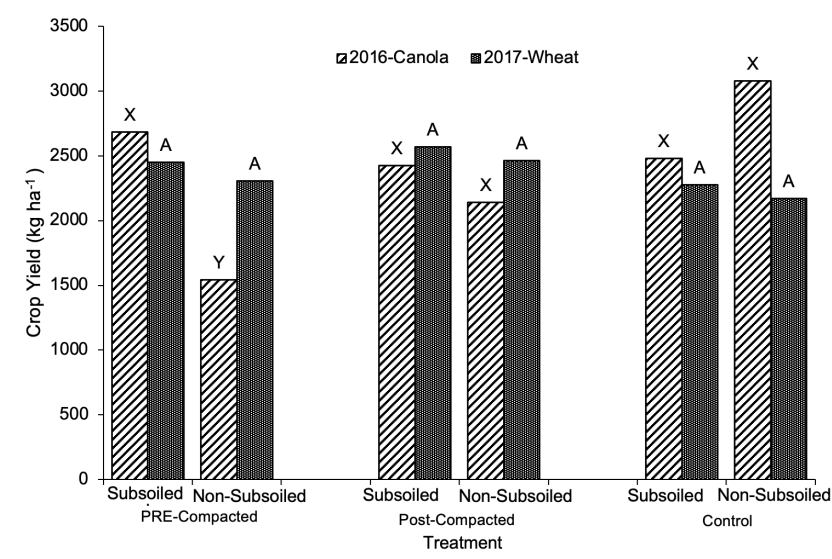

Fig. 4. Canola (2016) and wheat (2017) grain yields at the NCB site following subsoiling treatments in the fall of 2015. Pre-compacted is long-term (5-year) wheel traffic compaction prior to subsoiling, post-compacted is compaction by wheel traffic after subsoiling, and control is uncompacted soil. For a given crop component and compaction treatment, values followed by the same letter (2016 $X$ and $Y, 2017$ A) are not significantly different $(P>0.05)$.

were no significant differences among the treatments in hydraulic conductivity, but in 2017 the infiltration rate was slightly higher in all three subsoiled treatments. A reason for the observed increase in hydraulic conductivity in 2017 may be attributed to the lack of precipitation in 2017, such that the soil was unsaturated at the time of the infiltration measurement.

Crop yield At the NCB site in 2016, canola was grown to determine the subsoiling tillage effects on yield (Fig. 4). The long-term (5-year) wheel traffic compacted soil (precompacted) had significantly $(\mathrm{P} \leq 0.05)$ lower grain yield than the other treatments, and subsoiling increased the canola grain yield from $\sim 1500 \mathrm{~kg} \mathrm{ha}^{-1}$ to $\sim 2800 \mathrm{~kg} \mathrm{ha}^{-1}$ in the pre-compacted soil. This may be especially related to the effect of the subsoiling of the long-term wheel traffic compacted soil on reducing the soil strength below the critical value (Fig. 4) and enabling greater root exploration of the soil volume for water and nutrients, as this was the largest treatment effect on a physical property observed at this site. Compaction of the soil by wheel traffic that occurred post-subsoiling (post-compacted) did not significantly reduce the yield compared to the control. Still, yields tended to be lower, and there was a small benefit where the soil had been subsoiled prior to compaction.

The large amount of precipitation received at the site in this study in 2016 likely contributed to muting the crop yield responses to subsoiling of the uncompacted Solonetzic soil. Other studies have shown subsoiling tillage improved crop yield in similar soils (Grevers and de Jong, 1992, 1993).

In 2017, when hard red spring wheat was grown in the second year after the treatments, there were no significant subsoil treatment effects $(\mathrm{P}>0.05)$ on wheat grain yield
(Fig. 4). Wheat grain yield was similar among the treatments ranging from $\sim 2100$ to $2400 \mathrm{~kg} \mathrm{ha}^{-1}$. The effect of the compaction and subsoiling treatments on crop yield appears to have diminished over the 19 months since imposed, to the point where there was no impact on wheat yield in the 2017 crop year. A natural amelioration of the compacted condition by freeze-thaw and wet-dry cycles during 2016 and 2017, as well as the ability of wheat roots to more effectively penetrate dense soil compared to the canola grown in 2016, may explain the lack of compaction and subsoiling effects persisting into the second year after treatment. It is well documented that roots of many crops have reduced soil penetration abilities when resistance approaches levels of $\sim 2500 \mathrm{kPa}$ (Busscher et al., 1986; Kuang et al., 2012).

\section{CONCLUSIONS}

Reduced surface disturbance subsoiling to a $0.30 \mathrm{~m}$ depth in the fall was generally effective in reducing soil bulk density and strength (cone index) in the first year in noncompacted and compacted Chernozemic and Solonetzic soils. The degree of reduction in bulk density achieved by the implement was more significant in the Chernozem than in the Solonetzic soil. Lesser effects of subsoiling were observed on permeability in both soils, but it appears that air permeability at the surface is affected more by subsoiling than hydraulic conductivity. The only subsoiling treatment that produced a significant positive yield benefit was subsoiling on the long-term wheel traffic compacted Solonetzic soil. This was only observed in the first year, consistent with the Solonetz having significant root penetration/exploration issues, as evidenced by its very high soil strength values. The Chernozemic soils, with more organic matter and better structure than the Solonetzic soils, to begin with, appeared more resilient to compaction and tillage treatment.

Based on the responses to subsoiling tillage identified in this study, it is recommended that growers undertake efforts first to identify the specific soil types and compaction conditions most likely to produce positive yield response by using maps of soil type (e.g., Solonetzic vs. Chernozemic) and records of traffic history. Maps reflecting soil strength variations across the field area, obtained through soil penetration resistance measurements or other related assessments, may then be used to identify those areas in the field that would be most responsive to subsoiling and, therefore, most economically rewarding to apply this practice.

\section{ACKNOWLEDGEMENT}

The authors would like to acknowledge the financial support of the Saskatchewan Agriculture Development Fund, Saskatchewan Wheat Development Commission, Western Grains Research Foundation, and Sask Pulse Growers. Special thanks are given to Western Sales Ltd, Rosetown, SK, for providing equipment. The field and laboratory assistance of the Schoenau lab group members, particularly Cory Fatteicher, are gratefully acknowledged. 


\section{REFERENCES}

Bagarello, V., M. Iovino, and D. Elrick. 2004. A simplified falling-head technique for rapid determination of fieldsaturated hydraulic conductivity. Soil Science Society of America Journal. 68(1): 66-73.

https://doi.org/10.2136/sssaj2004.6600

Ball, B., and P. Schjønning. 2002. Air permeability. In: J.H. Dane and C.G. Topp, editors, Methods of soil analysis. Part 4. Physical methods. Soil Science Society of America Journal. 66(4): 1141-1158.

https://doi.org/10.2136/sssabookser5.4.c46

Borghei, A.M., J. Taghinejad, S. Minaei, M. Karimi, and M.G. Ghasemi Varnamkhasti. 2008. Effect of subsoiling on soil bulk density, penetration resistance, and cotton yield in northwest of Iran. International Journal of Agriculture and Biology. 10(1): 120-123.

Busscher, W.J., R.E. Sojka, and C.W. Doty. 1986. Residual effects of tillage on coastal plain soil strength. Soil Science Society of America Journal. 141(2): 144-148. https://doi.org/10.1097/00010694-198602000-00007

Busschera, W.J., P.J. Bauera, C.R. Campa, and R.E. Sojkab. 1997. Correction of cone index for soil water content differences in a coastal plain soil. Soil and Tillage Research. 43(3): 205-217. https://doi.org/10.1016/S0167-1987(97)00015-9

Cai, H., W. Ma, X. Zhang, J. Ping, X. Yan, J. Liu, J. Yuan, L. Wang, and J. Ren. 2014. Effect of subsoil tillage depth on nutrient accumulation, root distribution, and grain yield in spring maize. Crop Journal. 2(5): 297-307. https://doi.org/10.1016/j.cj.2014.04.006

Dexter, A. 1988. Advances in characterization of soil structure. Soil and Tillage Research. 11: 199-238. https://doi.org/10.1016/0167-1987(88)90002-5

Elzubeir, A.O. 2014. Influence of tillage systems on soil physical properties. American Journal of Agricultural and Biological Science. 4(4): 384-390. https://doi.org/10.9734/AJEA/2014/6706

Ewen, B. 2015. Effect of paraplowing on soil properties and crop yield under irrigated management. M.Sc. thesis. Saskatoon, Saskatchewan: Department of Soil Science, University of Saskatchewan.

Grant, C., and P. Groenevelt. 2008. Air permeability. In Soil Sampling and Methods of Analysis 2nd edition, ed. M.R. Carter and E.G. Gregorich, 803-810. Boca Raton, FL: CRC Press,. https://doi.org/10.1201/9781420005271.ch61

Grevers, M., and E. de Jong. 1992. Soil structure changes in subsoiled solonetzic and chernozemic soils measured by image analysis. Geoderma. 53(3-4): 289-307. https://doi.org/10.1016/0016-7061(92)90060-K

Grevers, M., and E. de Jong. 1993. Soil structure and crop yield over a 5-year period following subsoiling solonetzic and chernozemic soils in Saskatchewan. Canadian Journal of Soil Science. 73 (1): 81-91. https://doi.org/10.4141/cjss93-008
Hillel, D. 1980. Fundamental of Soil Physics, 1st edition, San Diego, CA: Academic Press.

https://doi.org/10.1016/B978-0-08-091870-9.50006-6

Huang, M., J. Zettl, L. Barbour, and D. Pratt. 2016. Characterizing the spatial variability of the hydraulic conductivity of reclamation soils using air permeability. Geoderma. 262: 285-293.

https://doi.org/10.1016/j.geoderma.2015.08.014

Kristýna, B., S. Lenka, and P. Pavla. 2013. Influence of water content on the shear strength parameters of clayey soil in relation to stability analysis of a hillside in Brno region. Acta Universitatis Agricultirae Silviculturae Mendelianae Brunensis. 6: 1583-1588.

https://doi.org/10.11118/actaun201361061583

Krzic, M., R. Newman, K. Broersma, and A. Bomke. 1999. Soil compaction of forest pantations in interior British Columbia. Journal of Range Management Archives. 52: 671-677. https://doi.org/10.2307/4003640

Kuang, B., H. Mahmood, M. Quraishi, W. Hoogmoed, A. Mouzaen, and J. van Henten. 2012. Sensing soil properties in the laboratory, in situ, and on-ine: a review. Advances in Agronomy, 155-224. San Diego, CA: Academic Press. https://doi.org/10.1016/B978-0-12394275-3.00003-1

McConkey, B.G., D.J. Ulrich, and F.B. Dyck. 1997. Slope position and subsoiling effects on soil water and spring wheat yield. Canadian Journal of Soil Science 77(1): 8390. https://doi.org/10.4141/S95-067

Mukhtar, S., J.L. Baker, R. Horton, and D.C. Erbach. 1985. Soil water infiltration as affected by the use of the paraplow. Transactions - American Society of Agricultural Engineers: General Edition. 28(6): 18111816. https://doi.org/10.13031/2013.32524

Mulqueen, J., J.V. Stafford, and D.W. Tanner. 1977. Evaluation of penetrometers for measuring soil strength. Terramechanics. 14(3): 137-153. https://doi.org/10.1016/0022-4898(77)90012-X

Murdock, L.W., D. Call, and J. James. 1999. Compaction, tillage method, and subsoiling effects on crop production. AGR-197. Lexington, Kentucky: College of Agriculture, University of Kentucky.

Osman, K. 2013. Physical properties of forest soils. In Forest soils, 12-44. Switzerland: Springer International Publishing. https://doi.org/10.1007/978-3-319-025414_2

Pikul, J.L., and J.K. Aase. 2003. Water infiltration and storage affected by subsoiling and subsequent tillage. Soil Science Society of America Journal. 67: 859-866. https://doi.org/10.2136/sssaj2003.8590

Soane, B.D., and C. van Ouwerkerk. 1994. Soil compaction in crop production, Amsterdam, Netherlands: Elsevier

Twum, E.K.A., and S. Nii-Annang. 2015. Impact of soil compaction on bulk density and root biomass of Quercus petraea L. at reclaimed post-lignite mining site in 
Lusatia, Germany. Applied and Environmental Soil Science. 1-5. https://doi.org/10.1155/2015/504603

Williams, J.D., S.B. Wuest, W.F. Schillinger, and H.T. Gollany. 2006. Rotary subsoiling newly planted winter wheat fields to improve infiltration in frozen soil. Soil and Tillage Research. 86(2): 141-151.

https://doi.org/10.1016/j.still.2005.02.019
Varsa, E.C., S.K. Chong, J.O. Abolaji, D.A. Farquhar, and F.J. Olsen. 1997. Effect of deep tillage on soil physical characteristics and corn (Zea mays L.) root growth and production. Soil and Tillage Research. 43(3-4): 219228. https://doi.org/10.1016/S0167-1987(97)00041-X

Zeleke, T.B., M.C.J. Grevers, B.C. Si, A.R. Mermut, and S. Beyene. 2004. Effect of residue incorporation on physical properties of the surface soil in the south central rift valley of Ethiopia. Soil and Tillage Research. 77(1): 35-46. https://doi.org/10.1016/j.still.2003.10.005 